\title{
SUCCESSFULNESS OF THE HUNGARIAN CITIES IN THE LIGHT OF A BUSINESS MARKET SURVEY
}

\author{
Zoltán KOLTAI ${ }^{\mathrm{a}}$ \\ ${ }^{a}$ University of Pécs, Faculty of Cultural Sciences, Education and Regional Development, Pécs-Szekszárd, \\ koltai.zoltan@kpvk.pte.hu
}

Cite this article: Koltai, Z. (2019). Successfulness of the Hungarian Cities in the Light of a Business Market Survey. Deturope. 11(3), 190-204.

\begin{abstract}
We made a layered questionnaire survey in 2005, in the framework of which we received replies from one thousand entrepreneurs and business leaders to our question relating to the competitiveness of Hungarian towns and cities. This research conducted more than ten years ago sought the answer to the following questions: what aspects do Hungarian businesses prefer when choosing their business location, which Hungarian cities are considered competitive by company leaders and why, which are the cities that the stakeholders see as real economic centres? In the light of the results, we repeated our survey in 2016-2017, allowing thereby the comprehensive evaluation of a period of ten years. In the second phase of data recording we used the method of a layered questionnaire survey again (the three aspects considered were as follows: breakdown of the Hungarian businesses by regions, company size and sectors), in which it was one thousand business managers again who responded to our questions.

The findings clearly demonstrate that the different parts of Hungary are characterised by different endowments and very diverse relative positions.
\end{abstract}

Keywords: successfulness, factors of business location, economic centre, Hungary

\section{INTRODUCTION}

Instead of the competition of regions it is much more appropriate now to talk about competition of cities, and this can even be further narrowed down to the competition of big cities with decision-making centres. Instead of the former determinants, good endowment with basic production factors, location of consumer markets, geographical distance, other factors are appreciated, like qualified human resources, innovation capacity of the population, high quality residential environment, leisure time facilities, quality of the city management, or city marketing. The importance of special local endowments is increasing in acquiring better competitive positions among settlements, conditions of the city competition are much less clearcut, or predetermined, than they were in the previous decades (Enyedi, 1996).

Features of successful settlements may be quite varied, from flexibly modifiable economic structure through highly qualified labour force and favourable social structure right to the environment of the settlement. Those European regions have become really successful that were able to define and operate a strategy on the basis of their own indigenous endowments. Such a 
strategy must always be closely related to the competitive advantages of the local businesses, so first we have to explore the potentially competitive sectors and also collect the factors from which their real competitive advantages can be derived from. Regions incapable of making programmes on their own can only temporarily stabilise their positions, and even that usually happens from the use of some central support, only. The goal of the research was to provide information for the elaboration of such a development strategy based on real local needs.

In our questionnaire we focused on the following issues, using three closed, three open and one semi-closed, so altogether seven questions: what aspects do Hungarian businesses prefer when choosing their business location, which Hungarian cities are considered competitive by company leaders and why, which are the cities that the stakeholders see as real economic centres?

\section{THEORETICAL BACKGROUND}

The interpretation of competitiveness during the survey is not restricted to an exclusively economic approach to the concept; it is seen as a broader, more complex issue also involving social and environmental aspects (Alderson, Beckfield \& Sprague-Jones, 2010; Camagni, 2009; Lengyel 2006; Lengyel 2012). Expanding the concept of competitiveness, successfulness also seems to be a concept suitable for the comparison of the development levels of regions and cities. In Lengyel's opinion, being successful is a category broader than competitiveness and lasting for a longer duration of time: “...regional competitiveness relates to the economy of the region, the actors of its economy and the closely related social factors, i.e. a category of regional economics, comprehensible in the short and middle run and strongly influenced by market cycles and innovation waves. Success, on the other hand, is a longer term category, also including extra-economic factors like the region's society, environment, settlement stock, geographical position etc.” (Lengyel, 2003, p. 290).

In successfulness, the importance of non-quantifiable characteristics in addition to measurable factors is emphasised by Boddy when attributing a special importance to the effective operation of local administration and the level of business services (Boddy, 2002). Under regional institutional system we can mean institutions themselves, the effective system of relationship among them, the quality and efficiency of, and trust in public administration, the so-called social capital. These characteristics will probably not differ much within a country but may very much different across nations, however.

The existence of the following actual factors can make a settlement or a spatial unit successful (Enyedi, 1997; Jensen - Butler 1997; Enyedi, 1998; Cheshire, 1999): 
- ability to change the economic structure (with special regard to the spread of sectors with value increasing and multiplier effect),

- high proportion of so-called value increasing sectors in the service industry (presence of high level business and financial services, research and development, higher education, high level cultural services),

- knowledge based production is typical (in connection with the significant consumption of the highly qualified labour, with their above-average demand for a high quality settlement environment, quality of life and services),

- the presence of innovation capacity and research and development is strong (chance of technology transfer),

- successful cities are cities that have power, decisions are made in successful cities, these are the places where corporate and financial centres are concentrated (concentrating thereby highly qualified employees with high incomes in the respective settlements),

- presence of strong and growing middle class (with above-average qualification and income), with favourable urban social structure (paradoxically, in practice this can coincide with significant social polarisation and emerging social conflicts),

- valuable settlement environment, adequate urban policy and provision of high quality public services (related to the non-material needs of the population),

- successful conflict management at a level acceptable for the public opinion, with the intention of preserving the social environment,

- significant external (international) relations, embeddedness in the urban relationship system of an international macro-region (which may be occasional trade relations as well as long-term information and network relations, and the development of external relationships requires background criteria like transport junctions, airline and railway connections or hotel capacities with adequate quality and quantity),

- increasing incomes and employment, as an effect of which significant amounts of develoment sources are raised from locally collected taxes (provided that the centralisation of taxes by the central state budget is not excessive, as in this case gaining the sympathy of the redistributing central power forces the application of totally different methods, separating urban development and the development of the local economy from each other). 
In the cases success is not an isolated phenomenon but leads to the birth of successful regions, development axes which will bring the competitiveness of a whole country or group of countries in the long run. It is a fact that the so-called global cities work in a network, and by being active participants in the (goods, financial and economic) decision-making processes of the world economy, their development is affected by intensive external forces. Their economy is basically of service character, while their society is multicultural and strongly layered. By today a clear division line has appeared in the developed countries between cities working inside global networks and cities excluded from these networks (Enyedi, 2012). Examples for researches on the centres managing and controlling global economy are also given by examinations of different authors. (Neal, 2011; Taylor et al. 2011a; Taylor et al. 2011b; Taylor \& Csomós2012)

Our analysis aimed also this time at allowing comparability, based primarily on statistical data with other researches. These researches made on the basis of complex surveys (Ambrus et al., 2008; Tóth, 2014), economic and labour market indices (Csomós, 2013; Tóth \& Nagy, 2013; Kiss \& Szalkai, 2014; Pénzes et al., 2014), on the ground of human resources and innovation (Grosz, 2011; Berkes, (2014) or environmental quality (Schuchmann \& Károlyi, 2009; Makra \& Sümeghy, 2010).

\section{OBJECTIVES AND METHODS}

In phase of data recording we used the method of a layered questionnaire survey (the three aspects considered were as follows: breakdown of the Hungarian businesses by regions, company size and sectors), in which it was one thousand entrepreneurs and business managers who responded to our questions. Taking the current breakdown of enterprises into consideration, more than $40 \%$ of respondents were from the region of Central Hungary, while all other regions were represented by an $8-12 \%$ proportion of respondents. Our qualitative survey features responses from all counties of Hungary. As regards company size, micro- and small enterprises have an above $96 \%$ share in our sample, while the sectoral breakdown is as follows: almost $80 \%$ were representatives of the tertiary sector, and agricultural businesses had a 3.5\% proportion. Thank to the personal interviews, almost all of the questionnaires filled out proved to be suitable for evaluation.

From the answers given to the first question we wanted to find out how much the location factors that we had collected were important when designating the place of operation. The aspects of our previous research (Koltai 2006; Koltai 2007) were supplemented with two new 
factors (demographic and social endowments, the international relations of the settlement), further increasing this way the range of possible answers. We asked respondents to evaluate the twelve aspects of competitiveness below on a five-grade scale:

1. economic structure of the settlement (e.g. sectoral breakdown, connected industries, suppliers' connections),

2. innovation culture and intellectual capital potential of the settlement (e.g. research and development capacities, presence of higher education institutions, number of research institutes),

3. regional accessibility relating to the geographical position of the settlement (e.g. transport infrastructure, accessibility of Budapest),

4. costs related to operation (e.g. wages, taxes and tax allowances),

5. activity of the municipality, settlement development policy (e.g. investment policy, city marketing, conflict resolution),

6. quality of the urban environment (e.g. attractiveness of residential place, natural environment, available medical, educational and recreational institutions),

7. supply of public institutions in the settlement (e.g. public services, operation of offices),

8. business services of the settlement (e.g. banking network, industrial parks, operation of business development offices),

9. qualification of labour force (e.g. schooling, language skills, work productivity, data of labour market),

10. the settlement's current or potential status as a consumer market (e.g. consumption potential, spending power, market size),

11. the demographic and social endowments of the settlement (age pyramid, migration processes, density of population),

12. international relations of the settlement (foreign businesses and investments, twin city relations, tourism).

\section{RESULTS AND DISCUSSION}

As it can be seen in Figure 1, respondents in 2005 put regional accessibility, the geographical position of the settlement to the first place, which is followed at some distance by being a consumption market. The next group consist of factors considered as medium important ones, including the presence of business services, the economic structure of the settlement, the costs of operation, the professional skills and productivity of labour force, and then come factors such 
as availability of public services, endowments of the settlement as a residential place and the settlement policy of the municipality. The lowest values were attributed on the whole to the innovation culture and the intellectual capacities of the settlement on the whole.

Figure 1 Importance of factors of business location, based on the responses of Hungarian businesses surveyed, 2005

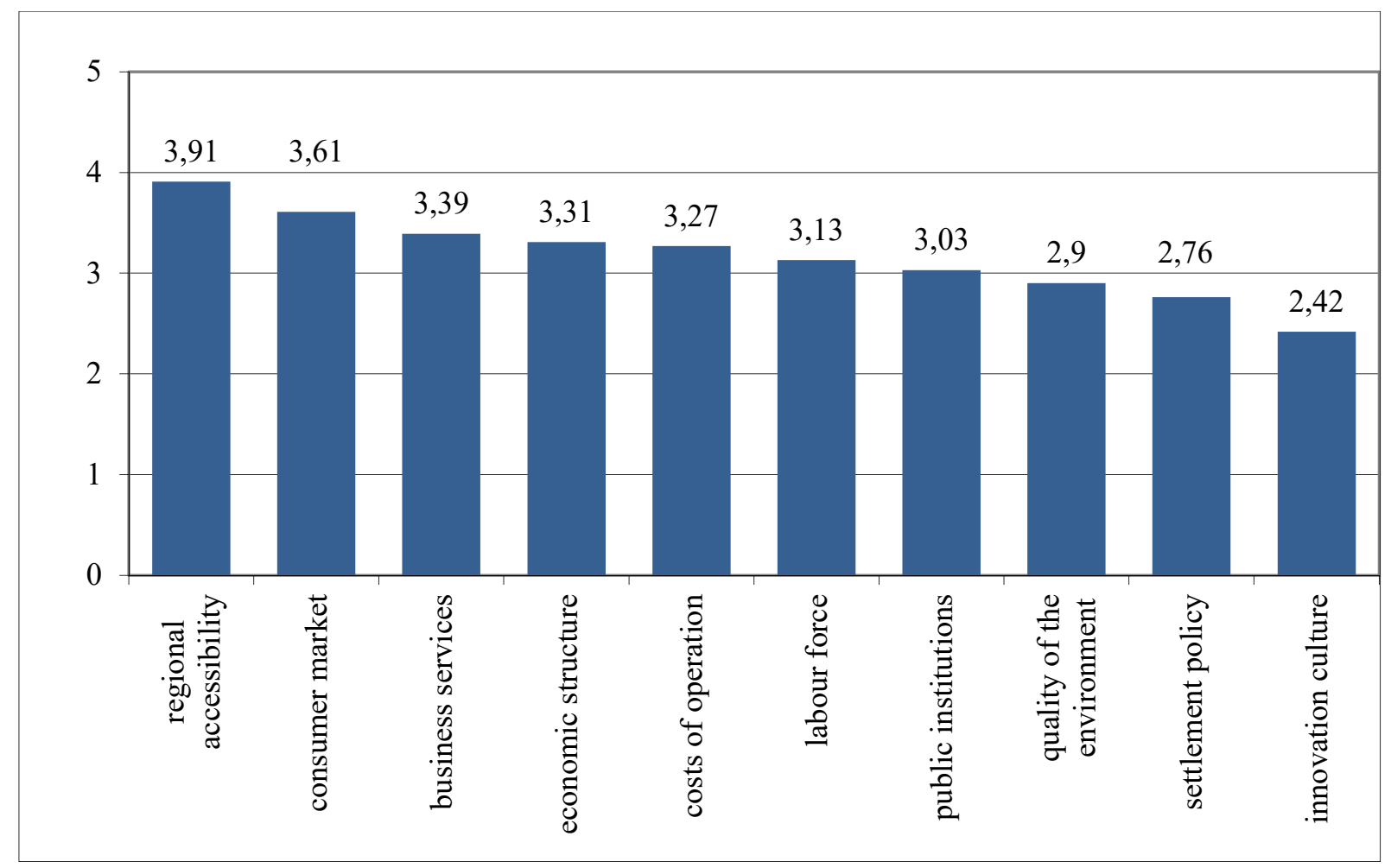

Source: questionnaire survey of the author (2005)

As our first hypothesis we expected the continued primacy of previously highly rated factors (regional accessibility, consumer market character), while we presumed that among the newly introduced aspects it would be the significance of the international relations of settlements that would be important, the latter especially for the middle-sized and large companies.

The findings of our new research show the costs related to operation are in the first place, followed by the regional accessibility and the consumer market character of the settlement (Fig. 2). The next group is led by the competence and efficiency of labour force, before the economic structure of the settlement, business services, the settlement policy of the local municipality, the quality of the environment and the supply of public institutions. Factors rated as the least important still involve innovation culture, and both of our new aspects, i.e. demographic and social endowments, and the international relations of the settlement can be found at the end of the list too. 
Figure 2 Importance of factors of business location, based on the responses of Hungarian businesses surveyed, 2016-2017

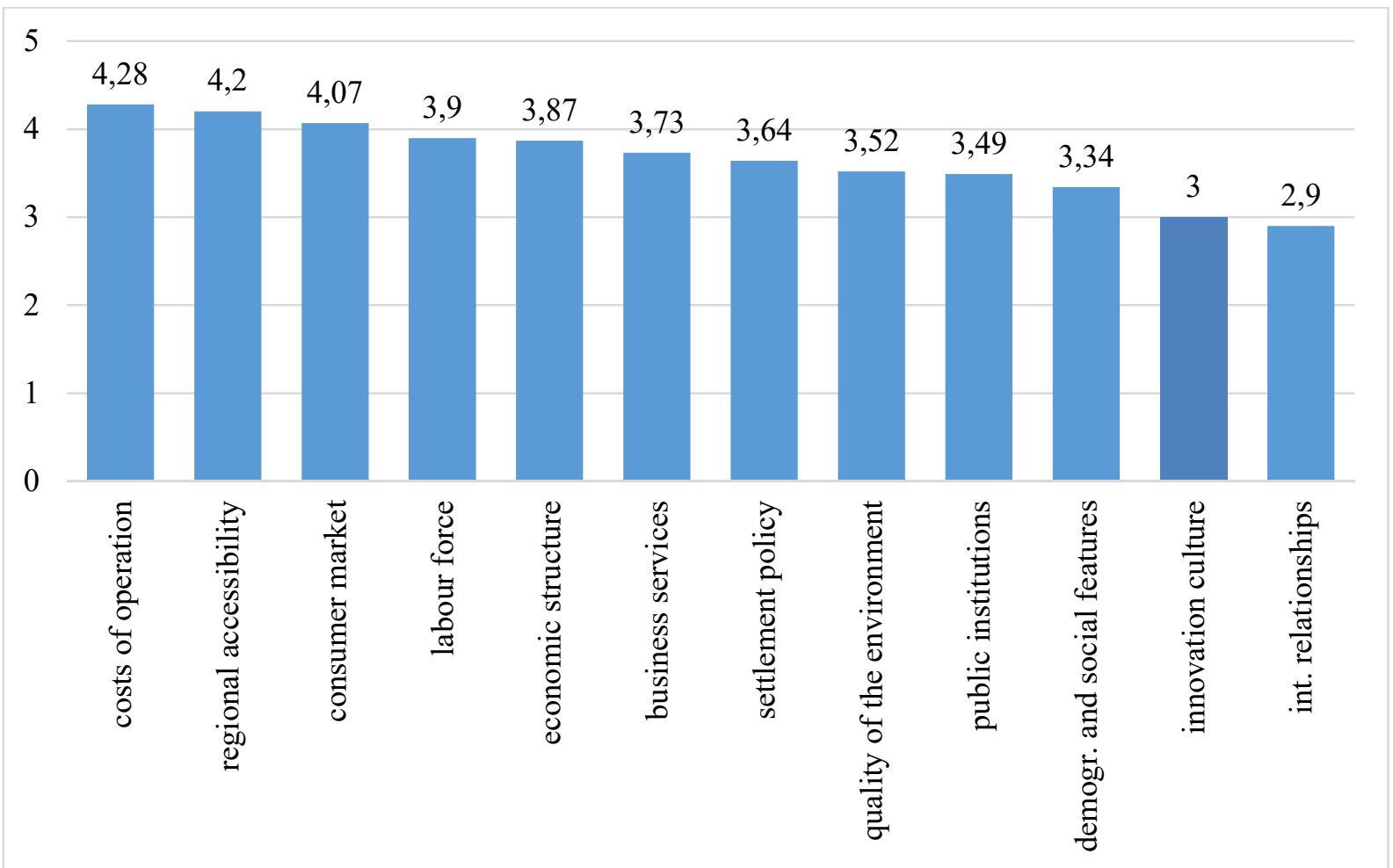

Source: questionnaire survey of the author (2016-2017)

All of our previous factors, with no exception, were given higher scores. A growth above the average could be seen at explanatory power of the settlement policy of the local municipality, the costs of operation, the competence of the labour force, the innovation culture of the settlement and the quality of the environment. We can state that the Hungarian businesses have become more cost sensitive in the past decade, on the one hand, and the existence or absence of skilled labour has been significantly appreciated for them, on the other hand. These changes are accompanied by the increased significance of the settlement policy activity of the local municipalities, which is visible from micro-businesses to large enterprises. Our first hypothesis was only partially verified, as the costs related to operation unexpectedly got position one in the ranking, also, the international relations of the settlements were rated as less important than we had expected.

Interesting tendencies are demonstrated by the examination of the scores given to the respective factors by the different size categories of businesses. Our second hypothesis defined was the appreciation of innovation culture by the large businesses, and we also expected that parallel to the increase of the size of the companies, the explanatory power of the consumer market character of the settlement and the quality of its environment would decrease. 
In our former research, the most important location factor was regional accessibility, geographical location, irrespective of the size categories. (In 2005 this was ranked first at all size categories of businesses; the highest value was given by large companies: the score was 4.21). This was now amended inasmuch as micro-, small and large enterprises now consider operationrelated costs as the most important location factor, whereas in the case of medium-sized enterprises it was the competence of the labour force that was given the highest value, which also was the overall highest value in the survey (4.48). The replies of micro-enterprises, because of their high share in our sample, fully coincided with the responses of the representative sample, and we did not find significant differences in the group of small enterprises (10-49 people), either. (The overall lowest value in the survey - 2.9 - was given by micro-enterprises; they said this was the significance level of the system of international relations.) As opposed to this, there are considerable differences among the responses of medium-sized enterprises (50-249 persons) and even more so of large businesses (above 250 persons). At medium-sized enterprises, as we have already indicated, the competence of the labour force was given the highest score, followed by, appreciated significantly again, the costs relation to operation, regional accessibility and the economic structure of the settlement. An aspect that grew in significance for the medium-sized enterprises is innovation culture, whereas the consumer market character of the settlement is now seen as much less important. Location factors that are seen as least important include demographic and social endowments, and the international relations of the settlement. According to the responses of the large companies, costs of operation evaluated as even more important are followed by regional accessibility and the competence of the labour force, and the economic structure and the innovation potential were also more appreciated by these companies (Fig. 3). In accordance with our expectations, at this level the consumer market character and the quality of the environment of the settlements are now taken as less important, which is an indication of the fact that large businesses typically do no produce for the local market and so the location of the operation is less typically considered as a place of residence but as a place of production by them. Our second hypothesis was then evidently verified.

Our third hypothesis was connected to the sectoral breakdown that was considered as a new factor in the 2016-2017 sampling. We expected that regional accessibility and geographical location, of outstanding significance in our previous survey, would be less important for the respondents from the services sector, whereas the consumer market character of the settlement would be more important for these businesses than for industrial and agricultural companies. We did no expect considerable intersectoral differences at any other factor. 
In the case of consumer market character there was indeed some appreciation in the tertiary sector, whereas regional accessibility is not less significant in the field of services than for other businesses. Although the agricultural actors slightly devaluate the significance of business services in a settlement, the majority of the factors do not show sector-specific marks at all. The research findings thus only partially verified our hypothesis.

Figure 3 Importance of factors of business location, based on the responses of large Hungarian businesses surveyed, 2016-2017

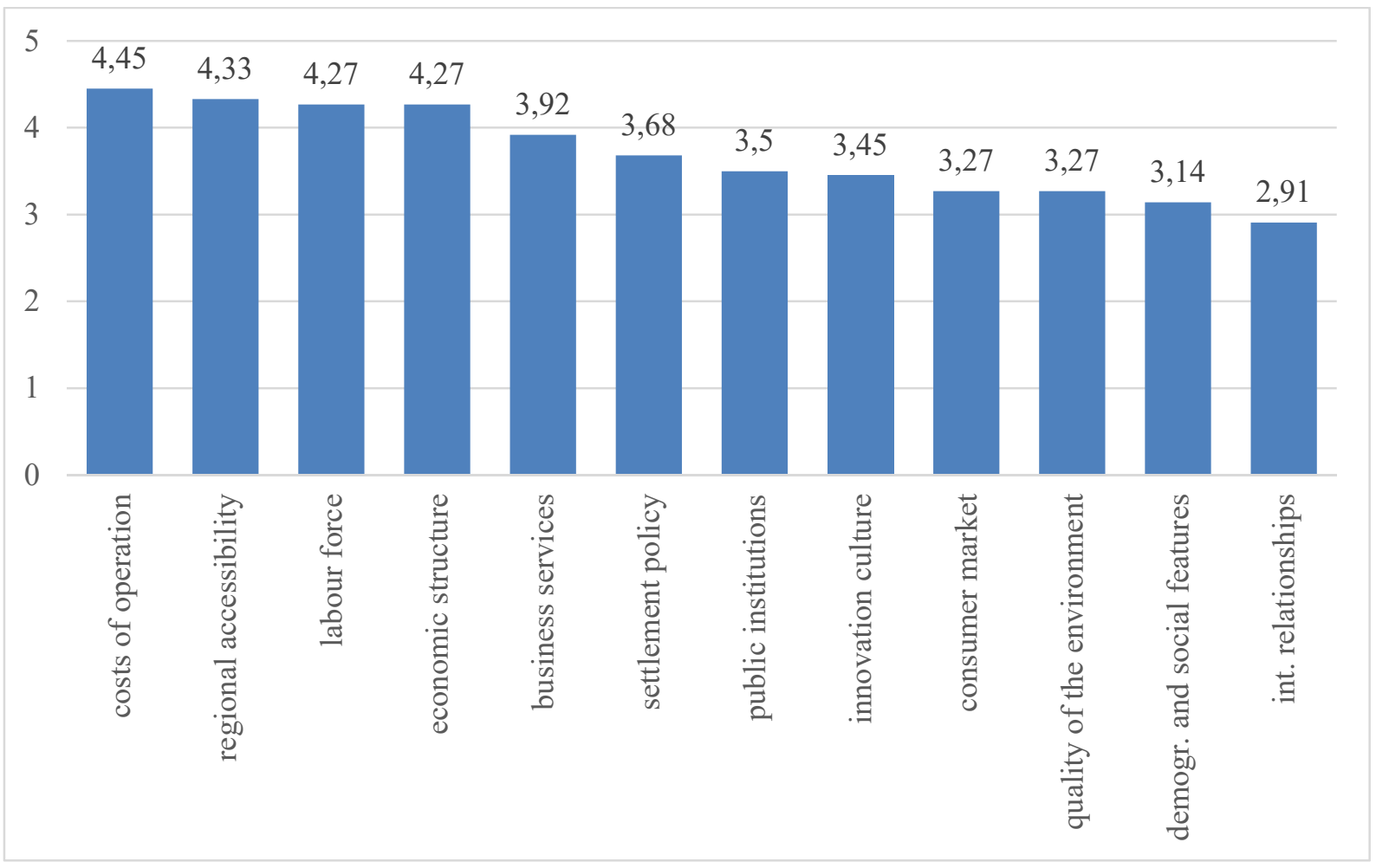

Source: questionnaire survey of the author (2016-2017)

\section{Assessment of the Attraction of Towns and Cities as Business Locations}

Useful information was provided by the part of the survey in which we asked businesses what factors they think can be found in the competitiveness of respective settlements. Of course both geographical comparisons (regional opinions vs. national assessments) and the temporal ones (changes experienced since 2005) make it difficult for us to create homogeneous groups of settlements. Nevertheless, we looked at the factors typical for towns given at least 50 mentions (12 towns), to see if the various factors showed any relation to the towns and cities. On the basis of the chi-square test (chi square $=452,37$; degree of freedom $=121 ; p$-value $<0.000$ ) we found a significant correlation between the features manifesting the attraction, and the towns and cities. Figure 4 visually demonstrates the characteristic features of the correlation. 
Figure 4 Correspondence map, based on the responses of Hungarian businesses surveyed, 2016-2017

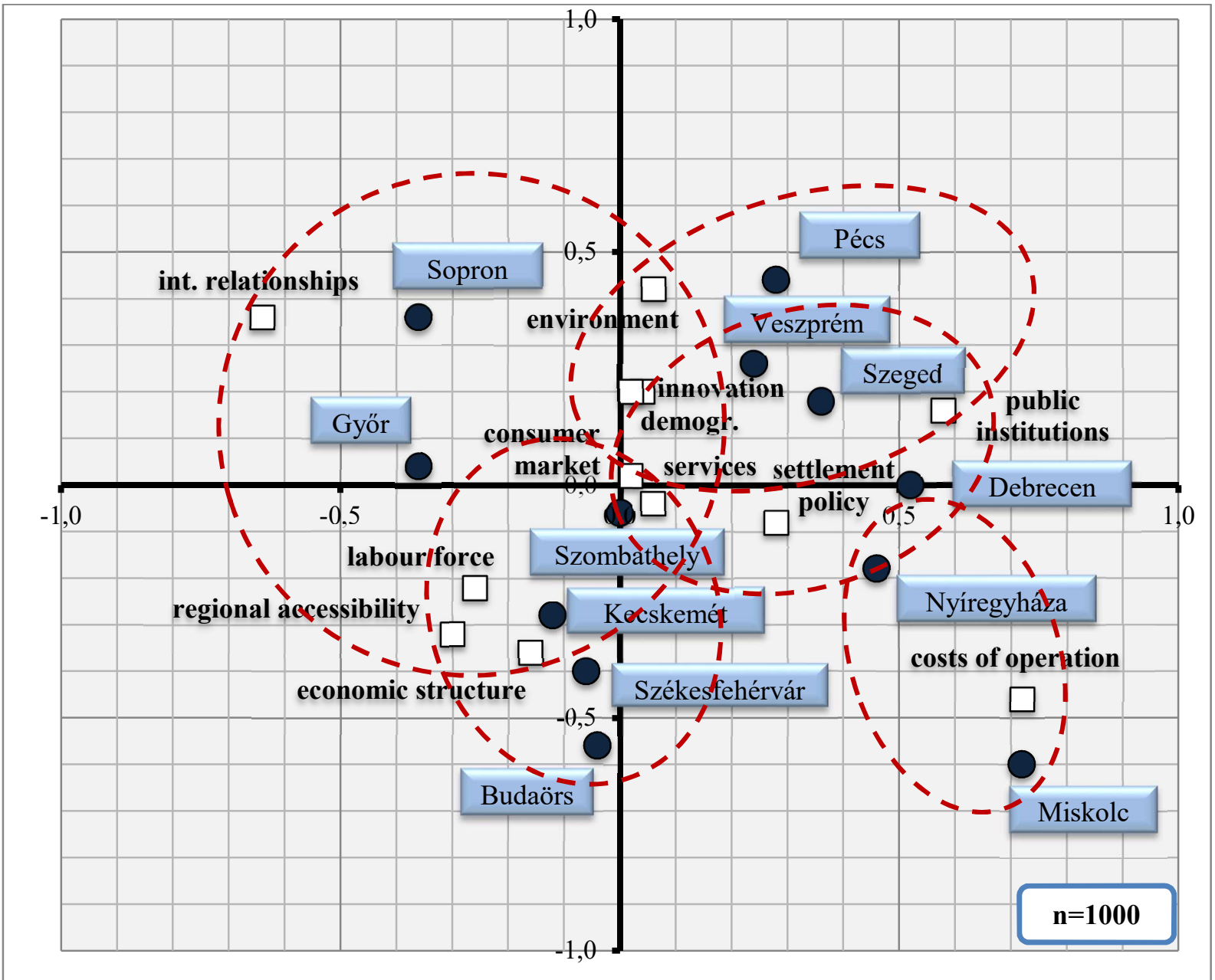

Source: questionnaire survey of the author (2016-2017)

There were six "clusters" that were the most visible:

- Győr can be interpreted as a category on its own, as no other countryside city possesses a similarly wide range of factors as Győr.

- The next group is made by Székesfehérvár, Kecskemét and Budaörs, but Szombathely can also be listed here, due to a partial overlap. The main features of cities in this category are good regional accessibility, a favourable economic structure and skilled labour force.

- The fact that Sopron is featured as a separate category is justified by the fact that this city gives a unique combination of the system of international relationships, highly esteemed urban environment and a significant local consumer market.

- Pécs, Szeged and Veszprém are in the same group primarily due to the quality of their urban environment and their supply of public institutions; the first two cities are also similar to each other as regards their innovation cultures. 
- Debrecen and Nyíregyháza approach the former group of cities with their range of public institutions, but in their case this is mostly matched by the active participation of the municipal self-governments (settlement development policy) and favourable operational costs.

- The latter factor, favourable operational costs is a feature of Miskolc, which is actually not coupled with any other location factor.

\section{Hungarian Centres from the Companies' Perspectives}

The next question of our research aimed at what settlements are considered by the businesses as real centres of gravity in Hungary. According to our previous findings, Budapest appeared as a centre in all regions of Hungary, what is more, in five of the regions the capital city of Hungary was mentioned most frequently as the centre in 2005. In South Transdanubia, the region that was an exception, where was Pécs was seen as the primary centre of gravity then, while in the North Great Plain Debrecen was indicated in most of the cases.

Our fourth hypothesis is that business leaders see Budapest as the dominant centre in all of the regions, and we also expect the appreciation of the central functions of Györ and Kecskemét.

During our previous research Budapest was seen as the centre of gravity in the region of Central Hungary primarily due to its services, in the second place as a place of procurement and sales of products. Formerly the respondents of this region also listed Székesfehérvár among the cities with considerable attraction, not it was Kecskemét that was mentioned most frequently after Budapest. The central functions of the capital city are also due now to its wide range of business services in the first place, further reinforced by the supply of public institutions, its favourable transport infrastructure, and the consumer market character and its favourable economic structure.

In the region of the South Great Plain Szeged was mentioned more frequently in 2004-2005 among the regional centres than Kecskemét, but the latter was one of the few cities that were qualified as centres also outside their own regions. (Kecskemét was mentioned as a city with central functions in the North Great Plain, Székesfehérvár in Central Hungary and Győr in Middle Transdanubia, as a supplementation to the opinion that says Budapest is the only city in Hungary with attraction reaching beyond its own region.) Currently it is still Budapest that is the number one centre of gravity in the South Great Plain, followed by Kecskemét and Szeged. Both South Great Plain cities are seen as centres due to both their business services, supply of public institutions and their role in the procurement and sales of products. 
As revealed from the replies of the businesses in South Transdanubia, the primary centre now is Budapest, and besides Pécs it was Kaposvár that was sometimes mentioned. The central character of Pécs and Kaposvár is due to their wide range of business services in the first place, secondarily to their consumer markets. (In the case of Szeged and Pécs we can rightly miss among the explanations of the central functions the aspect related to innovation culture, research and development capacity, which is an indication of the less dominant role of this factor again.)

In the North Great Plain Budapest is followed by Debrecen and Szolnok. The position of Debrecen among the centres is due primarily to its favourable economic structure and system of suppliers, while Szolnok is in this circle due to its business services. (In the case of Debrecen, factors considered as important in the previous questions, like business services, the range of public institutions or the consumer market character, were now less frequently mentioned.)

In the coming three regions it was not Budapest but cities within the respective regions that were seen as primary centres of gravity. In Middle Transdanubia more businesses consider as the centre Székesfehérvár than Budapest, coming from the business services, the transport infrastructure, the supply of public institutions and the favourable economic structure of Székesfehérvár. Factors of secondary importance included the innovation culture and the consumer market character of this city.

In North Hungary Miskolc was mentioned most frequently, Eger was less often visible in the replies. Miskolc was primarily specified by the businesses of the region as a centre due to its business services, in the second place because of its public institutions, economic structure and transport infrastructure. The explanation in the case of Eger is the supply of public institutions. (For Miskolc the consumer market character mentioned in the regional replies was less emphasised now.)

Finally, in West Transdanubia it was not only Györ but also the other two county centres of the region, Szombathely and Zalaegerszeg that were given more mentions as centre than Budapest. The factors contributing to this are primarily business services, their supply of public institutions and their transport infrastructure. (In the case of Győr, similarly to Szeged and Pécs, the explanatory role of innovation culture and the research and development capacity is less typical.) Our hypothesis was verified, as the centre of gravity character of Budapest can be detected in all of the regions, while Győr and Kecskemét were able to strengthen their central functions primarily within their own regions. 


\section{CONCLUSION}

It tells a lot that the number one attraction of cities as business locations in Hungary is cost related to operation now. This is followed by factors quite constant over a ten-year period like regional accessibility relating to the geographical position of the city and the city's current or potential status as a consumer market. The lowest values were attributed on the whole to the innovation culture and international relationships of the city on the whole.

According to our expectation, the consumer market character and the quality of environment of the settlements was seen as factors of lesser importance by large businesses, which indicates that at this level, businesses usually no longer produce for the local market, and the location must be less suitable as a place of residence than a business location in the first place. Innovation culture was significantly appreciated in this circle.

In the case of consumer market character there was indeed some appreciation in the tertiary sector, whereas regional accessibility is not less significant in the field of services than for other businesses. Although the agricultural actors slightly devaluate the significance of business services in a settlement, the majority of the factors do not show sector-specific marks at all.

In Hungary there is still very close correlation between the favourable assessment of cities and their positions in the city hierarchy. It is still true that primarily the Hungarian big cities are considered as competitive and successful business locations. The centre of gravity character of Budapest can be detected in all of the regions, while Györ and Kecskemét were able to strengthen their central functions primarily within their own regions.

The goal of measuring success in the territorial sense in my opinion is to assess the position of a given territorial unit as objectively as possible, and on this ground to look at what needs to be done for its development. It is important to realize in what a respective settlement differs from other settlements of similar size and functions, because the competition among towns and cities has many actors of similar endowments, therefore some speciality must be found. If we accept that the goal of competition is to enhance the well-being of the local residents, we can also say that the tool of successful participation in the competition is a special, but flexibly modifiable development programme based on the partnership of and operating in the coordination of local politics, businesses, the civil sector and the academic sphere; a development programme that the local stakeholders know and support as well.

Of course we are aware of the fact that a considerable group of the attractions of the settlements is not exclusively fromed by local decision-makers, and that only longer term programmes can lead to favourable changes in many cases. Nonetheless we think that 
responsible development concepts that are specific, maybe concern exact target groups in the settlements and strive for long-term economic success can never neglect personal experiences, and the utilisation of them in a complex regional view.

\section{REFERENCES}

Alderson, A. S., Beckfield, J. \& Sprague-Jones, J. (2010). Intercity Relations and Globalisation: The Evolution of the Global Urban Hierarchy, 1981-2007. Urban Studies, 47(9), 18991923.

Ambrus, Z., Kissné Majtényi, M., Kólyáné Sziráki, Á. \& Malakucziné Póka, M. (2008). Nagyvárosok összehasonlító vizsgálata. Területi Statisztika, 48(2), 136-163.

Berkes, J. (2014). A megyei jogú városok, mint innovációs potenciál hordozók. Deturope, 6(2), 121-130.

Boddy, M. (2002). Linking Competitiveness and Cohesion. In I. Begg (Ed.), Urban Competitiveness. Policies for Dynamic Cities (pp. 33-52). Bristol: The Policy Press.

Camagni, R. (2009). Territorial Capital and Regional Development. In R. Capello \& P. Nijkamp (Eds.), Handbook of Regional Growth and Development Theories (pp. 118-132). Cheltenham: Edward Elgar.

Csomós, G. (2013). Magyarország gazdasági központjainak pozícióváltozása 1992 és 2011 között. Területi Statisztika, 53(6), 529-550.

Enyedi, G. (1996). Regionális folyamatok Magyarországon az átmenet időszakában. Budapest: Hilscher Rezső Szociálpolitikai Egyesület.

Enyedi, G. (1997). A sikeres város. Tér és Társadalom, 11(4), 1-7.

Enyedi, G. (1998). Sikeres régiók. In A. Kereszty (Ed.), Tények könyve: régiók (pp. 409-411). Budapest: Greger-Delacroix.

Enyedi, G. (2012). Városi világ. Budapest: Akadémia Kiadó.

Grosz, A. (2011). A hazai vállalkozások innovációs és K+F-tevékenységének területi különbségei. Területi Statisztika, 51(3), 211-226.

Jensen-Butler, C. (1997). Competition Between Cities, Urban Performance and the Role of Urban Policy: a Theoretical Framework. In C. Jensen-Butler, A. Shachar \& J. van Weesep (Eds.), European Cities in Competition (pp. 3-42). Aldershot-Brookfild: Averbury Publishing Company.

Kiss, J. P. \& Szalkai, G. (2014). A foglalkoztatás területi koncentrációjának változásai Magyarországon a népszámlálások ingázási adatai alapján, 1990-2011. Területi Statisztika, (54)5, 415-447.

Koltai, Z. (2006). A magyar lakosság és vállalati szféra lakó-, illetve telephelyválasztásának szempontjai. Területi Statisztika, 46(3), 240-254.

Koltai, Z. (2007). A magyarországi városok versenyképességének vállalati megítélése. Tér és Társadalom, 21(2), 23-42.

Lengyel, I. (2003). Verseny és területi fejlödés: Térségek versenyképessége Magyarországon. Szeged: JATEPress.

Lengyel, I. (2006). A regionális versenyképesség értelmezése és piramismodellje. Területi Statisztika, 46(2), 131-147.

Lengyel, I. (2012). Regionális növekedés, fejlődés, területi tőke és versenyképesség. In Z. Bajmócy, I. Lengyel \& G. Málovics (Eds.), Regionális innovációs képesség, versenyképesség és fenntarthatóság (pp. 151-174). Szeged: JATEPress. 
Makra, L. \& Sümeghy, Z. (2010). Magyarországi városok és megyék osztályozása infrastrukturális és környezeti indikátorok alapján. Földrajzi Közlemények, 134(2), 203215.

Neal, Z. (2011). Differentiating Centrality and Power in the World City Network. Urban Studies, 48(13), 2733-2748.

Pénzes, J., Molnár, E. \& Pálóczi, G. (2014). Helyi munkaerő-piaci vonzáskörzetek az ezredforduló utáni Magyarországon. Területi Statisztika, (54)5, 474-490.

Schuchmann, P. \& Károlyi, J. (2009). A magyar nagyvárostérségek természeti környezeti, táji és az épített környezet átalakulásával összefüggő egyenlőtlenségei. In V. Szirmai (Ed.), A várostérségi versenyképesség társadalmi tényezői (pp. 86-90). Budapest-Pécs: Dialóg Campus.

Taylor, P. J., Ni, P., Derudder, B., Hoyler, M., Huang, J., Pain, K., ... Shen, W. (2011a). Command and Control Centres in the World Economy. In P. J. Taylor, P. Ni, B. Derudder, M. Hoyler, J. Huang \& F. Witlox (Eds.), Global Urban Analysis: A Survey of Cities in Globalization (pp. 17-21). London: Earthscan.

Taylor, P. J., Derudder, B., Hoyler, M., Pain, K. \& Witlox, F. (2011b). European Cities in Globalization, In P. J. Taylor, P. Ni, B. Derudder, M. Hoyler, J. Huang \& F. Witlox (Eds.), Global Urban Analysis: A Survey of Cities in Globalization (pp. 114-136). London: Earthscan.

Taylor, P. J. \& Csomós Gy. (2012). Cities as Control and Command Centres: Analysis and Interpretation. Cities, 29(6), 408-411.

Tóth B. I. (2014). A hazai kistérségek vonzerejének és területi tökéjének néhány összefüggése. Területi Statisztika, 54(1), 3-18.

Tóth G. \& Nagy Z. (2013). Eltérő vagy azonos fejlődési pályák? A hazai nagyvárosok és térségek összehasonlító vizsgálata. Területi Statisztika, 53(6), 593-612. 